\section{THE UNIVERSITY OF SHEFFIELD.}

\section{THE VIELD LABORATORIES AND PHARMACO- LOGICAL DEPARTMENT.}

\section{SIR WALTER FLETCHER}

ON

\section{MEDICAL RESEARCH AND DAILY LIFE.}

The new Field Laboratories of the University of Sheffield are now working at full capacity, and on November 2nd wer visited by a party of panel practitioners in the neighbourhood.

The Field Laboratories were erected last year at the request of Professor Edward Mellanby on his acceptance of the chair of pliarmacology in order that his work on experimental rickets and other dietetic problems, which he had been carrying on in London and at Cambridge, might be trans ferred to Sheffield. The sum already expended on the erec tion of the buildings and their equipment is $£ 7,000$, and towards this the Panel Committee contributed $£ 1,000$, thus affording evidence of the living interest of insurance practitioners in scientific research in medicine.

The buildings of the Field Laboratories have been erected in a field rather more than three acres in area, situated on the edge of the moors at an altitude of nearly $1,000 \mathrm{ft}$. and about four miles from the university and six from the centre of the city. The buildings consist of a series of army huts suitably modified for their various purposes. One of these (60 by $20 \mathrm{ft}$.) is used as a residence for the caretaker and assistant. Direct access is provided into a second hut, which is divided in to three rooms; one is a chemical and histological laboratory another is used for post-mortem examinations, and the third for weighing and preparing the food for the animals. Between the laboratory and the main building which is used for housing the animals there is a store room in which anthracite, sawdust, and chips are kept. The animal house measures 80 by $30 \mathrm{ft}$., and is divided into three rooms, which lead into one another; these rooms provide separate accommodation for 65 puppies. A second building, about forty yards from the main gı oup, will be erected for isolation purposes and for treating infective conditions, but owing to the lack of funds this has not yet been completed. At their visit last week the party was afforded the opportunity of seeing the experiments now in progress. The majority of these are designed to throw light on the etiology of several well-known diseases. The extraordinary differences in the growth structure of tissues and general activity of the animals produced by small diff rences in diet were very clearly to be seen.

In an informal manner Professor Mellanby demonstrated the effect of different diets in the production of rickets. A series of dental specimens, which illustrated the work of Mrs. Mellanby on the influence of diet on dentition, were shown also. Most impressive of all, perhaps, were the remarkable effects on the appearance and activities of puppies fed on different diets.

After the inspection the party returned to the university, where, after tea, they assembled to hear an address from Sir Walter Fletcher, M.D., F.R.S., Secretary of the Medical Research Council. The Vice-Chancellor, in introducing Sir Walter Fletcher, in a few words thanked the practitioners for their help and support.

MEDICAL RESEARCH AND DAILY LIFE.

Sir Walter Fletcher said that the Medical Research Council was grateful to the University of Sheffield for the unique arrangements made for the research work conducted by Professor Mellanby and his immediate colleagues, but especially was it grateful for the singular generosity which had inspired members of the medical profession in Sheffield to give important financial support to that part of the work which was being done at the Field Laboratories. The Medical Research. Council was making a large annual con tribution to the work, but its means were strictly limited and it was a very great encouragement to have voluntary support. It was especially encouraging when support was given directly by members of the medical profession. It was not the case of a benevolent millionaire, though he hoped there might be many sich, giving a generous donation towards scientific work as to the nature of which he was imperfectly instructed; but it was the case of men who really knew the meaning of the work giving it support.
Grateful as the Council was for that financial co-operation, it was the interest that generosity evidenced which was specially welcomed. Those interested in the advance of know. ledge by scientific research work in the field of medicine needed the help of medical men, at every turn, wherever it was a question of making available for the benefit of the public the practical fruits of research work. There were many directions of inquiry in which the laboratory man was helpless unless the man of practical experience of human needs was closely co-operating with him. That co-operation wight almost be taken for granted, but the research worker needed also the help of the profession as interpreters to the public. The laboratory man was buried in the laboratory, and little seen by the public. But the doctor went everywhere, and had the necessary knowledge to guide and enforce public opinionhitherto backward in this country-which was to support research; public interest and knowledge must be moulded and stimulated by medical men.

"I was reading last week," the speaker continued, "that delightful essay by John Brown of Edinburgh upon Sydenham. Writing in the last generation, long before this most recent busy output of pathological and physiological work, he looked into the future and said that the progress of scientific knowledge affecting medicine was going to increase in a manner which would defy all calculation, and he said that it would have the most important effect upon the quality of the medical profession. He prophesied that the office of physician would in a high sense become more difficult than before, because it would require a greater compass and energy of mind-it would be working in a wider field and with finer weapons. Surely that prophecy has been fulfilled, and the medical man of to-day is working with an incomparably greater compass and incomparably finer weapons than his predecessors of only a generation ago."

Sir Walter Fletcher went on to speak on the general topic of his address-the obvious and visible importance of medical research work in the daily life of the community. The ordinary layman, who put himself unquestioningly in the hands of the physician or surgeon, and accepted all the resources brought to bear to help him, was necessarily little aware of the laborious researches upon which those resources from large measures of treatment down to tiny points of technique, were based. Research workers had difficulty in bringing home to the public how the work they did bore fruit in practical life outside the technical field of the operating theatre or the medical ward. Research work did not get, or until recently had not got, the same public support and encouragement-and gratitudefrom Englishmen as it had received, and was receiving, in countries like Germany and America. The Englishman was in some ways paradoxical. $\mathrm{He}$ was characteristically kind-hearted; he hated pain, and if pain were presented to him he desired to help it. British charities for the diminution of suffering were earlier, and had been more generously supported, in this country than in any other, and our nursing services have been earlier and better than those of any other country. But the Englishman was not so imaginative as the instructed public of those other nations. If the pain was stopped, or at least if it were out of his sight, he forgot it, and he did not think so deeply of the importance of preventing it for the future. The sums of money given in this country for the removal of immediate pain and immediate disease and suffering were enormous when compared with the trifling amounts offered either by gift or bequest for the scientific research work by which alone secure advances could be made towards the permanent prevention or further palliation of suffering. There were two ways in which the research worker and his work were apt to be undervalued and underestimated. All work which aimed at prevepting pain and disease suffered under a conspicuous handicap. The more successful it was, the less obvious the results. If a disease were practically abolished, as for example small-pox in this country, the boon was easily forgotten. "I am just old enough," the speaker said, "to remember what a pock-marked face is like. I should say that very few of the undergraduates in this room know really what I mean when I speak of a pock-marked face. They have probably no vivid visual recollection of that, and yet their grandfathers could remember a time when a girl's chances of marrying were enormously increased if she were not pock-marked." A more recent example was the inestimable triumph of the virtual abolition of enteric fever and its congeners during the late war. It had often been spoken about, but it was already being rapidly forgotten. 
In the South African war very many more men died from the bacillus than from the bullet. But in the late war, owing to research work diligently pursued in the interval in the Army Medical Sorvice, the position was exactly reversed, and, for the first time in recorded history, there were more deaths from the bullet or the shell than from disease. Enteric fever was practically negligible in our army, in spite of the incredibly insanitary conditions of most of the fighting area. Had the lesson really sunk home in the minds of the people of this country?

"I noticed quite lately," Sir Walter Fletcher continued, "two war memorials in the same village-one for the South African war, aud one close by for the late war, the great war. I noticed with interest that upon the south African memorial there are a few names, a handful of names, of those who were killed by bullet or' shell, and then a long list of those who 'died from illness'-which meant enteric fever. Close by was the memorial to those who fell in the great war, unhappily with a much greater roll of names, but not one of those had died from enteric disease. Imagine what it would be if by some magic you could see inscribed, in any given village, the roll of the names of those who would have died but for that research work. The roll of names would be much longer than the mournful roll of those who actually fell, and it would keep alive our debt of gratitude to the men who produced that result. Yet it was only in the last session that more than a liundred members of Parliament voted in the House of Commons in favour of a resolution that no further public money should be spent upon medical research work. More than a hundred members of Parliament voted in favour of Kenworthy's b ll, which would preclude for all future time-until it was rescinded, as future generations would rescind it-any similar research work on behalf of the Army, or the Navy, or for any other Government department, or in the universities of the country, supported by public funds."

There was another kind of difficulty. When the fruits of research had been gathered in-and this was especially true of results of research work like much of that done at the Field Laboratories, which touched the practical daily life of m inkınd-there was a persistent tendency on the part of what was called the practical man to say "Yes, but of course we knew that before: common sense would have told us that." An old saying, which contained a great deal of truth, was that in this country any scientific discorery was submitted in successive stages to three kinds of criticism. In the first stage men said frankly that they did not believe it, that it was untrue; in the second stage that it was contrary to the doctrines of the Christian religion; and in the third that they knew it before. 'The "knew it before" attitude was very common, especially in the field of medical research.

Of this the speaker gave two definite instances: "When I went from Cambridge to London to begin my present work in 1914, shortly bufore the war, I met the Minister of the department which is in duty bound to take chief interest in the results of medical research work, and he was good enough to have a long talk with me on the terrace of the House of Commous. And I remember he cheerfully and frankly said to me, 'Well, doctor' (I have never pretended, then or since, to be a doctor)- ' well, doctor, I don't hold with research. If we want to stop disease we must give the people better grub and less dirt.' Now that was the con sidered opinion of a responsibie Minister. There is, of course much truth in what he said, that given 'better grub' and given 'less dirt' disease would be incalculably lessened in this country; and my reply of course was that I entire!y agreed -if he could tell me what better grub was and what less dirt was, for I know no way of finding out those two things except by persistent scientific research work."

"As we look back now we can see how clear a guide has already been given us in many directions towards knowing what 'better gr'ub' means, by scientific work only made possible by public expendituce." Oî this illustrations were at hand in some of the work in the Sheffield laboratories. The nation ought to be very proud of the studies of vitamins going on so actively, not only in Sheffield but in other centres of research work: proud because the fundamental discovery underlying it all was made in this country. The whole subject, so to speak, had been the almost exclusive property of the English-speaking races. The Americans had actively pursued it, but the Germans, the Austrians, the Frenchso active in other directions of research work, especially before the war-were still far behind us in this vitally important subject.
The fruitful-and practical applications of the work were immediate and obvious. Further knowledge must simplity the process of getting knowledge, but at present such inve.ti. gations were expensive, because they had to be done slowly, by the use of animals. But they told us about "better grub" for the people. Already, although we were still ignorant, only at the dawn of the subject, although even Professor Mellanby had, the speaker felt confident, no clear idea in his mind when he used the word "vitamins" in regard to their chemical nature or the mode of their actionalready there was abundant practical fruit, a circumstance quite unusual in the history of the growth of science: the British housewife could now be advised, and should now be advised by the proper authorities, of the differences to the present aud future lives of her children that depended upon whether she gave them butter or margarine; the differences between one kind of butter and another kind of butter; the time for which she boiled the cabbage (that was a matter of very great importance, or minht be, to the lives of her children); and whether she should use lard or other forms of fat; other illustrations would be familiar to medical men. It was being said thet all that was "kuown before." It was obrious, some people said, that milk would be better if it came from a cow eatiug green grass than if it was eating liay in the winter, and so on. Well, if all this was known before those who knew it and concealed the secret were homicidal criminals. Those who had seen some of the experimental work at the Sheffield Field Laboratories would know the tremendous power of control over the bodily shape and bodily health of the animal which relatively minute differences of diet would bring about. And the study was yet in its infancy : much more work was urgently needed, yet it was possible now to look forward coufidently to a time when immeasurable benefit could be brought to the populations of our great cities through this work. Yet more than a hundred members of the last Parliament voted against its continuance.

There must have been very few during the war who did not notice, with a good deal of heart sinking, the passage of the Australians and New Zealanders about our streets, with their splendid figures and faces, who did not reflect sadly that these men were of the same bone and blood as ourselves, and yet seerned to be members of a superior race as compared with the ordinary Londoner; if they had come in the samo numbers to Sheffield the contrast might have been even more marked. There was a time co:ning, to which scientific research work was fairly pointing the way, when it would be regarded as a shameful anomaly if the average Englishman was not at least as finely developed in body and face as those men were. "I hope," Sir Waiter Fletcher said, "I may live to see the day when beauty again of that type comes back to the faces of the populations of our great cities.'

He could not stay to touch upon the interesting new work about the action of light, and the rumarkable way in which sunlight or artificial light, falling upon the skin, seemed able to do part of tile work done ordinarily by vitamin substances in food. There again the common-sense man said, "Ouly a fool could ever doubt that sunshine is good for man. We knew it before." That was true, but in our northern island vast numbers of our fellow countrymen lived in smoky citiez, and the knowledge of how to supply by appropriate artiticial means proper artificial light, and if necessary food-the equivalent of the rich man's holiday time on the Rivierawould work untold benefits to this country. From a purcly scientific point of view there was hardly any more interesting chapter in biology than that now opening, which seemed to point to cod-liver oil as being, in some literal truth, bottled sunlight; we might have to depend upon artificial light and artificial conditions of food until the results of the industrial revolution were palliated and we had built Jerusalem again in " England's green and happy land."

"So much," Sir Walter Fletcher said, "for grub. I had meant to say something about dirt, the lessened dirt that my friend thought would do so much for the diminution of disease. But what is dirt? Let us think of the soldiers in the trenches. It was wholly impracticable to say, 'Let them be clean.' It is impracticable to tell a coal miner to be clean. Almost all our industrial population are in a sense waging a kind of warfare where personal cleanliness of the ordinary kind is impossible during the hours of labour. But it was not dirt in the ordinary sense of the word that injured the soldiers. It was not the mud of the trenches. That brought them nothing beyond inconvenience. It did not bring them death unless it was dirt of a particular kind, and only the scientific 
man was able to say what were the dangerous kinds of dirt, and how they could be avoided-liow scabies could be prevented, which was one of the greatest sources of loss of man power during the war; how tetanus, coming from the soil, could be prevented; low typhus and trench fever could be liept at bay by tracing out the exact mode by which those diseases are conveyed from man to man by lice, where not mere cleanliness is sufficient, but measures which are effective to destroy parlicular insects. And in the mines of Cornwall it is not dirt which injured the men's health, but over a large district it was hookworm disease, where the particular stage of the parasite entered through the skin, and so spread the infection; and a knowledge of tlie precise mode of propagation was sufficient to stamp out the disease. Many are the instances of that lind that will occur to everyone here.

"So many of our opponents---because we luave opponents, as well as those who are merely passive-the opponents of medical research work are fond of saying that this or that triumph of medical science is the result of improved sanitation. That can he definitely disproved in mauy instances. But even our draiugage, the enforcement and development of our drainage schemes, has throughout been stimulated and guided by a growing precision in our know. ledge of the organisms of discase. Evcn now research is activoly in progress, and is still needed. Research is needed into the new process, the activated sludge method, recently installed in sheffield. It appears to be completely successful, but it is not perfectly understood, and we may be certain that until it is perfectly understood it can never be constantly successful, and there will always be times when something may go wrong without an available remedy.

"I am sometimes tempted to think that the stimulus of research work has driven sanitation too far. Our knowledge as it has grown has, I think, shown that a great deal of the modern plumbing which is insisted upon by various by-laws is really unvecessary, and dates from a time when a mysterious agent called effluvium was supposed to convey dis. ease. I firmly believe that the cost of housing might be cut down in an important way if science were allowed full play, as it is in some parts of America, in the devices which are now used.

"I should not like to leave the subject, especially when speaking in a university, without trying to remove any impression I may have given that $I$ or any other scientific man, or any of the research workers of the country, are thinking all the time of the material benefits they can produce. They have prcduced those material benefits, and all mankind owes them gratitude, but it is not for these mere additions to our ccmfort that these men are working, and it is not merely for the practical fruits that, in my opinion, the public support and public money should be given. It is quite unnecessary, in a place of this kind; to point to the value of knowledge for its own sake. In the instances I have briefly touched upon, where I have appeared perlıaps chiefly to think of the practical boons conferred, the interest and beauty of the scientific work involved is very great indeed. This kind of work in any civilized nation is needed not only for utility, though Heaven knows that is justification enough, but for its interest and its delight, for our self-respect and for the dignity of man, and, 1 would add, for our worship. After all, the second great commandment about loving our neighbour cannot be more than an empty sentiment nowadays unless the love takes a practical form, and unless it is free, so far as possible, from ignorance. This scientific work is necessary for the fulfilment of that commandment. It is necessary, too, for the fultilment of the other great commandment. That consideration has, I think, never been better expressed than by a physician, Sir Thomas Browne. You remember he said: "The wisdom of God receives small honour from those vulgar heads that rudely stare about and with a gross rusticity admire His works. Those highly magnify Him who by deliberate research into His creatures and juaicious inquiry into His acts return the duty of a devout and learned admiration.',

Sir Walter was heartily thanled for his address on the proposition of Dr. Arthur Hall, seconded by Dr. Forbes, secretary of the Sheffield Panel Committee. In reply, he said: I know that my Council have it in view to ask Sheffield, if I may use so comprehonsive a word, to undertake another very important piece of work, and I hope I may take back a favourable answer with regard to that when I return.

\section{SMALL-POX IN LONDON.}

THE total number of cases of small-pox reported in and near London during the year 1922 down to November 4th is 62, with 17 deaths; that is greater than in any year. since 1904. Reference to the following table slows that this figure is possibly comparable with the 63 of 1891 and with the 66 of 1900. Each of these figures was followed by a heavy outbreak in the following year; the outbreak which appears now to be impending may be further postponed, as it has already been postponed, both by the improvement in public education on the subject of small-pox and by the heightened efficiency of the public health service; but there is no doubt whatever that the present external pressure of small-pox on the one liand, and on the other the negative internal susceptibility to the disease, brought about by the $\mathbf{n} \in$ glect of vaccination, have reached such a point that an adjustment is extremely likely to take place by means of a smart if not a heavy epidemic.

\begin{tabular}{|c|c|c|c|c|c|c|c|c|}
\hline \multirow{2}{*}{ Year. } & \multicolumn{2}{|c|}{$\begin{array}{l}\text { Deatbs fiom } \\
\text { Small-pox }\end{array}$} & \multirow{2}{*}{$\begin{array}{l}\text { Admis- } \\
\text { sions to } \\
\text { M.A. } \\
\text { Hospitals }\end{array}$} & & \multirow{2}{*}{ Year. } & \multicolumn{2}{|c|}{$\begin{array}{l}\text { Deatbs } f_{1} \mathrm{~cm} \\
\text { Small-pox. }\end{array}$} & \multirow{2}{*}{$\begin{array}{l}\text { Admis- } \\
\text { sions to } \\
\text { M.A.B. } \\
\text { Hospitals }\end{array}$} \\
\hline & $\begin{array}{l}\text { Engiand } \\
\text { nnd } \\
\text { Wal:s. }\end{array}$ & Loniton & & & & $\begin{array}{c}\text { Engl nd } \\
\text { and } \\
\text { Wales. }\end{array}$ & Lo: don & \\
\hline $\begin{array}{l}1881 \\
1882 \\
1883 \\
1884 \\
1885 \\
1886 \\
1887 \\
1888 \\
1889\end{array}$ & $\begin{array}{r}3,098 \\
1,317 \\
957 \\
2,234 \\
2,827 \\
275 \\
506 \\
1026 \\
23 \\
16\end{array}$ & $\begin{array}{r}2,367 \\
430 \\
136 \\
1,236 \\
1,317 \\
20 \\
9 \\
9 \\
9 \\
1 \\
3\end{array}$ & $\begin{array}{r}8,551 \\
1,799 \\
598 \\
6,263 \\
6,146 \\
99 \\
56 \\
62 \\
5 \\
22\end{array}$ & $\begin{array}{l}\text { Cases } \\
\text { certi- } \\
\text { fied in } \\
\text { Eng. } \\
\text { land } \\
\text { and } \\
\text { Wales. } \\
\end{array}$ & $\begin{array}{l}1901 \\
1 \leq 0 \\
1903 \\
19 c 4 \\
1 \subseteq 05 \\
1906 \\
19 i 7 \\
1908 \\
1.01 \\
1010 \\
1911\end{array}$ & $\begin{array}{r}356 \\
2,464 \\
760 \\
507 \\
116 \\
21 \\
10 \\
12 \\
21 \\
19\end{array}$ & $\begin{array}{r}229 \\
1,314 \\
13 \\
25 \\
10 \\
0 \\
0 \\
0 \\
0 \\
2 \\
0\end{array}$ & $\begin{array}{r}1,743 \\
7,842 \\
355 \\
449 \\
53 \\
27 \\
2 \\
1 \\
15 \\
5\end{array}$ \\
\hline $\begin{array}{l}1891 \\
1892 \\
1893 \\
1894 \\
1895 \\
1896 \\
1897 \\
1898 \\
1899\end{array}$ & $\begin{array}{r}49 \\
431 \\
1,457 \\
8: 0 \\
223 \\
541 \\
25 \\
253 \\
174 \\
85\end{array}$ & $\begin{array}{r}8 \\
29 \\
186 \\
89 \\
55 \\
9 \\
16 \\
1 \\
3 \\
4\end{array}$ & $\begin{array}{r}63 \\
325 \\
2,36 \\
1,117 \\
941 \\
1 \leq 0 \\
70 \\
5 \\
18 \\
66\end{array}$ & $\begin{array}{r}124 \\
116 \\
66 \\
92 \\
151 \\
7 \\
64 \\
297 \\
263 \\
336\end{array}$ & $\begin{array}{l}1912 \\
1013 \\
1914 \\
1 \div 15 \\
1915 \\
1917 \\
1918 \\
1919 \\
1920 \\
1: 21\end{array}$ & $\begin{array}{r}9 \\
10 \\
4 \\
13 \\
18 \\
3 \\
2 \\
25 \\
29 \\
5\end{array}$ & $\begin{array}{l}1 \\
0 \\
0 \\
3 \\
0 \\
0 \\
0 \\
5 \\
4 \\
0\end{array}$ & $\begin{array}{r}5 \\
1 \\
1 \\
11 \\
1 \\
0 \\
36 \\
27 \\
18 \\
2\end{array}$ \\
\hline
\end{tabular}

'The present run of cases began with the disclosure at a consultation on October 27th, 1922, at St. Andrew's Hospital Broinley-by-Bow, formerly the Poplar and Stepney Sick Asylum, of a case of small pox in the person of an inmate who had been admitted from the Poplar institution, formerly the Poplar worklsonse, on October 24th, 1922. On October 27 th a rash appeared on his skin, and he was remored that evening to the small-pox receiving station of the Metropolitan Asylums Board. Vaccine lymph was sent for by special messenger, and vaccination of the immediate contacts was begun the same evening. Revaccination of all of the staff of the hospital has been brought up to date, and nearly all of the inmates have now been revaccinated. The risk of a spread in this institution is minimized owing to this case having been detected on the same day that he became. infectious, and to the prompt measures which have been taken.

On the morning following this occurrence-namely, on Saturday, October $28 \mathrm{th}$-consultations were held on certain cases in the Poplar institution, and as a result there were at once certified fire cases of small-pox from two of the men's wards. There was thus suddenly disclosed a most serious situation, inasmuch as there was then reason to suspect that further cases of small-pox were scattered throughout the institution. This, in fact, proved to be the case. Apprehension also arose that infection might have been conveyed outside owing to the free ingress and egress of the inmates and staff.

A rapid plan of operations to meet the emergency was at once drawn up, embracing the following main indications: (1) to search for every further existing case; (2) to remove or destroy the infection thus disclosed, by prompt transfer of the patients and immediate disinfection; (3) to protect the contacts as far as possible by raccination, and to watch for further cases arising; (4) to ascertain the origin of the outbreak.

Various remedial steps, falling under one or other of these main heads, were taken almost simultaneously. All ingress to and egress from the institution was at once stopped. Immediate notice was given to the Poplar Borough Council, the London County Council, and the Ministry of Health. 